\title{
A.R. FAKHRUDDIN WAJAH TASAWUF: DALAM MUHAMMADIYAH
}

\author{
Oleb: Masyitob*
}

\section{Abstract}

With emphasizing to truth Islam and refusal to taqlid, bid'ab and churafat, Muhammadiyah has appreciation to Islamic mysticism (read: akblaki Islamic mysticism). Altbough Islamic mysticism is more individual necessity and the term bas never been mentioned, but many of Mubammadiyah figunes practice Islamic mysticism individually. It was began from founder of Muhammadiyab, K.H. Abmad Dablan and others figures, such as: Ki Bagus Hadikusumo, KH. Mas Mansyur, Buya Hamka, AR. Fakbruddin,etc. A.R Fakbruddin bim self can be addressed as Kadda an yukunu Suufiyan (near to be a Sufi), in this case Sufi Akblagi. It is caursed by all akblakul karimah characteristics bave already mixed up in bis soul, such as: patient, thank God, Wara Zubud, Qana'ab, Tawakkal, Ikblas, Rịsha, etc. In the meantime, bis spiritual life which fills more of bis life and it is reflecting Islamic mysticism attitudes. $A$ Sufi's live can be reflected from bis attitude and thought about: taubat, taqarrub, dqikullah, kbusyu', tawaddbu', khauf, raja, muraqobah, and istiqamab, these maqam are common to be done in Islamic mysticism world.

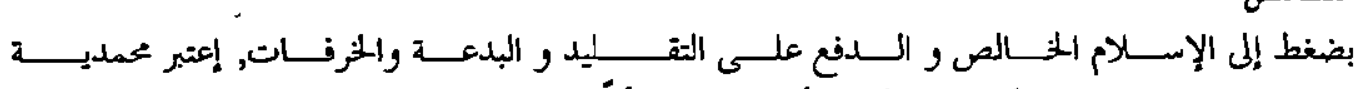

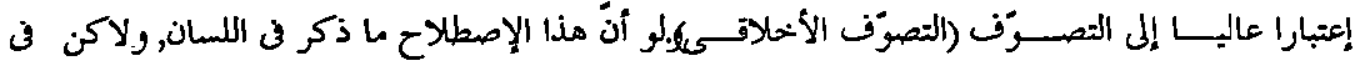

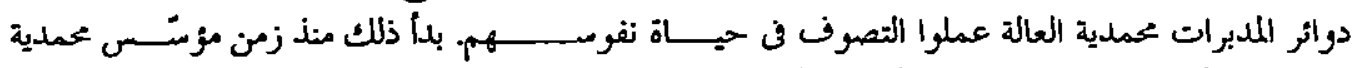

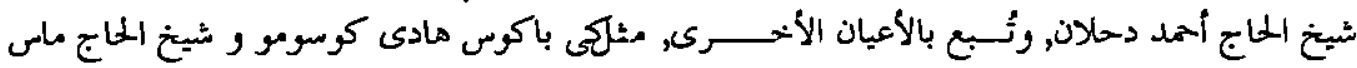

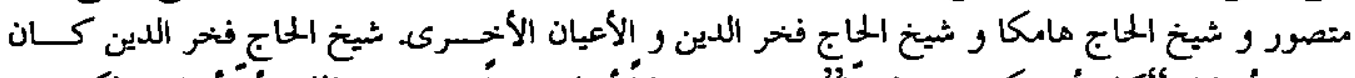

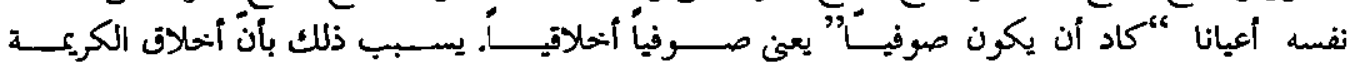

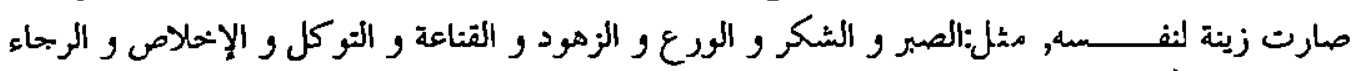

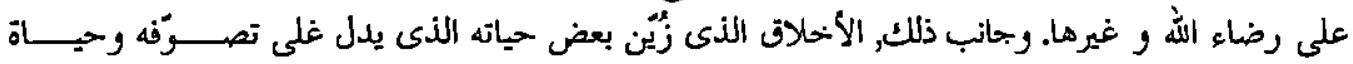

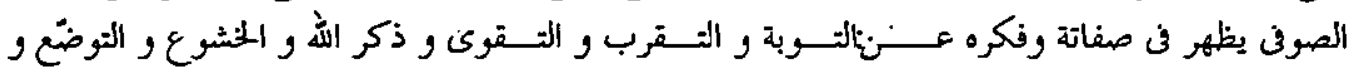

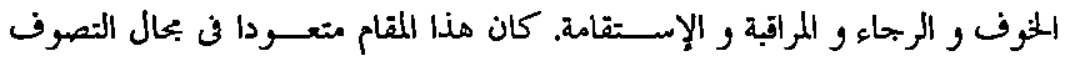

Keyword : Mubammadiyab, mysticism, Sufi Akblaqi, Spiritual and maqam.

* Dosen FAI dan Magister Studi Islam Universitas Muhammadiyah Jakarta, dan kini sedang memegang amanah sebagai Rektor UMJ. E-mail : info@umj.ac.id atau masyitoh@umj.ac.id 


\section{A. Pendahuluan}

Lahimya gerakan Muhammadiyah di awal abad ke-20, tepatnya pada $8 \mathrm{Dzulhijjah}$ $1330 \mathrm{H}$, bertepatan dengan 18 Nopember 1912, paling tidak, karena dipengaruhi oleh getakan tajdid (reformasi, pembaruan pemikiran Islam) yang digelorakan oleh Muhammad ibn 'Abd al-Wahhab (1703-1792) di Arab Saudi, Muhammad 'Abdub (1849-1905), Muhammad Rasyîd Ridhâ (1865-1935) di Mesir, dan lain-lain. Masingmasing tokoh tersebut memiliki corak pemikiran yang khas, berbeda satu dengan yang lain. Jika Muhammad ibn 'Abd al-Wahhâb menekankan pemurnian akidah, sehingga gerakannya lebih bersifat puritan (purifikasi), maka Muhammad 'Abduh lebih menekankan pada pemanfaatan budaya modern dan menempuh jalur pendidikan, dan karena itu, gerakannya lebih bersifat modernis dan populis.

Sementara itu, Rasyîd Ridhâ menekankan pentingnya keterikatan pada teksteks al-Qurân dalam kerangka pemahaman Islam, yang dikenal dengan al-Rujä́ ilâ al-Qur'ân wa al-Sunnab (kembali kepada al-Qur'an dan al-Sunnah). Oleh karena itu, gerakannya lebih betsifat skriptualis (tekstual), yang kelak menjadi akar fundamentalisme (al-usbâlizyab) di Timur Tengah. ${ }^{1}$ Dari telaah biografi KH. Ahmad Dahlan, terlihat bahwa betapa pendiri Muhammadiyah itu sangat terkesan dan sedikit banyak terpengaruh oleh pemikiran-pemikiran tokoh di atas yang kemudian dipadukan dan dikontekstualisasikan dengan setting sosial dan budaya Jawa, dan masyarakat Indonesia pada umumnya. Ketika itu, masyarakat Indonesia berada dalam kondisi terjajah, terbelakang, mundur, miskin, dan keberagamaan sebagian mereka cenderung mengidap penyakit TBC (Tahayul, Bid'ah, dan Cburafat).

Sebagai gerakan tajdîd (pembaruan), dalam memahami dan melaksanakan ajaran Islam, Muhammadiyah memang mengembangkan semangat tajdid dan j̈̈tibâd (mendayagunakan nalar rasional dalam memecahkan dan mengambil kesimpulan berbagai masalah hukum dan lainnya yang tidak ada dalilnya secara eksplisit dalam al-Qur'an dan al-Sunnah), serta menjauhi sikap taklid (mengikuti ajaran agama secara membabi buta, tanpa disertai pemahaman yang memadai terhadap dalil-dalilnya), sehingga di samping dikenal sebagai gerakan sosial keagamaan juga dikenal sebagai gerakan tajdid.

Wilayah ijtibadd dan tajdid Muhammadiyah sejak awal sebenamya selalu terfokus pada persoalan historisitas kemanusiaan yang sekaligus juga menyentuh persoalan kebangsaan dan keumatan. Masalah pengentasan kemiskinan melalui jahur pendidik-

${ }^{1}$ Syafiq A. Mughni, Muhammadiyab dan Pemikiran Keagamaan dalam Muhammadiyah Menyongrong Abad 21, (Yogyakarta: LPPI, LP3M, FAI, UMY, Pustaka Suara Muhammadiyah, 1998), hal. 17. 
an dan pelayanan kesehatan merupakan persoalan keumatan yang kongkrit dan otentik. Sikap dan aksi nyata seperti itulah yang dilakukan oleh pendiri Muhammadiyah pada awal berdirinya dan terus berlangsung hingga kini. Karena etos amal kemanusiaan dan keagamaan ini perlu mendapat ruang dan respons yang lebih luas dari warga Muhammadiyah dan lainnya.

Nafas Muhammadiyah sebagai gerakan tajdid, sesungguhnya terletak dalam pergumulannya dengan persoalan historisitas keberagamaan manusia. Untuk membangkitkan dan menyegarkan kembali gerakan pembaruan pemikiran keagamaan Muhammadiyah dalam konteks pembangunan umat, tidak lain dan tidak bukan adalah dengan cara mencermati kembali makna normativitas teks-teks (nash-nash) al-Qurân dan al-Sunnah secara lebih kontekstual, dengan cara mengaitkan dan mempertautkannya secara langsung atau kontekstualisasi dengan persoalan-persoalan sosial-historis keberagamaan Islam kontemporer secara aktual. ${ }^{2}$

Sebagai pelopor pembaruan pemikiran Islam khususnya di Indonesia, baik yang bercorak purifikatif (pemumian akidah-ibadah) maupun rasionalistik (bidang muamalah duniawiyah), Muhammadiyah telah menyumbangkan sesuatu yang paling mendasar, yakni sikap kritisnya terhadap status quo pemikiran keislaman saat kelahirannya maupun dalam perjalanan kehidupan bangsa. Selain itu, keunikan corak pembaruan yang dibawa Muhammadiyah adalah terletak pada sisi amaliahnya yang menekankan kesalehan sosial, seperti pembangunan lembaga pendidikan, rumah sakit, panti asuhan, masjid serta sarana dakwah lainnya.

Dalam konteks purifikasi, al-Qurân dan al-Sunnah al-sbabîbab (yang valid) secara tekstual normatif merupakan paradigma utama dalam komitmen aqidah maupun pelasanaan ibadah mabdhah. Dari paradigma tekstual normatif ini melahirkan doktrin segala sesuatu diyakini dan dilaksanakan bila ada perintah (al-Quran dan al-Sunnah). Sedangkan dalam konteks rasionalisasi, al-Quran dan al-Sunnah al-shabîhah juga tetap menjadi rujukan pokok, namun dalam keyakinan dan pengamalan bidang muamalah duniawiyah ini berlaku kaidah ushul: al-asbl fi al-asyyâ' al-ibabab (semua urusan muamalah duniawiyah boleh dikerjakan) selama tidak ada larangan atau tidak bertentangan dengan al-Quran dan al-Sunnah.

Sebagai sebuah organisasi pembaruan keagamaan, Muhammadiyah memang berpandangan bahwa kunci kemajuan dan kemakmuran kaum Muslimin adalah terletak pada perbaikan pendidikan. Oleh karena itulah, sesungguhnya sejak dulu

${ }^{2}$ M. Amin Abdullah, "Muhammadiyah dan Pemikiran Keagamaan" dalam Syafiq A. Mughni, ibid, hal. 6-7. 
nama organisasi ini diambil dari nama sekolah yang didirikan oleh Ahmad Dahlan satu tahun sebelum didirikannya Muhammadiyah. ${ }^{3}$

Gerakan Muhammadiyah juga sejak awal dikenal luas sebagai gerakan sosial keagamaan yang didirikan untuk mengadaptasikan Islam dengan situasi modern Indonesia, karena gerakan ini menegaskan diri sebagai gerakan pembaruan yang peduli dan konsen (care and concern) terhadap kemajuan Islam dan umat Islam, dan menyebabkan kebangkitan kembali kaum Muslimin di Indonesia.

Sebagai pelopor gerakan pembaruan pernikitan Islam yang lebih mengutamakan aspek rasional dalam beragama (meskipun akhir-akhit ini tidak sevokal dan seagresif dahulu) dan menekankan pentingnya peranan akal serta pendidikan akal, ternyata dalam praktik pemimpin dan anggotanya banyak yang mencerminkan dan menekankan pentingnya kehidupan spiritual yang sangat dekat dengan wilayah tasawuf. Keharusan hidup untuk mensucikan jiwa (akhlak) yang bersumber dari ajaran agama dan berkehendak menaati seluruh perintah Allah berdasarkan Kitab Allah dan Sunnah Rasulullah SAW. serta "menyifatkan dirinya dengan sifat-sifat Allah", merupakan ciri dan perilaku kehidupan tasawuf. Meskipun perilaku seperti itu pada zaman Rasul tidak disebut tasawuf, karena istilah atau laqab (julukan) sufi pada saat itu belum ada. Istilah ini baru muncul pada akhir abad dua atau awal abad tiga hijriyah. ${ }^{4}$ Ibn Taimigah (661-728 H) menyatakan bahwa ahli agama, ahli ilmu dan ahli ibadah pada saat itu disebut kaum salaf, yang kemudian disebut dengan shufizyah wa al-fuqara ${ }^{5}$

Perilaku dan kehidupan spiritual sejumlah pemimpin Muhammadiyah, dilakukan seiring dengan pelaksanaan pemberantasan bid'ah, syirik dan khurafat serta desakralisasi praktik beragama, seperti praktik beragama (baca: bertasawuf) model Ibn Taimiyah. Orang-orang yang masuk ke dalam kategori ini (sufi) adalah mereka yang sungguh-sungguh menaati Allah. Di antara mereka ada yang lebih utama karena kesungguhannya dalam ketaatannya pada Allah dan adapula yang masih dalam tahap penyempumaan, mereka disebut dengan abl al-yamin. ${ }^{6}$ Sementara itu, Imam al-Ghazali

${ }^{3}$ Djamawi Hadikusumo, Matabari-Matahari Mubantmadiyab (Yogyakarta, t.t), hal. 72. Bahwa sekolah keagamaan pertama yang menggunakan bangku dan papan tulis adalah sekolah-sekolah agama Muhammadiyah yang didirikan pada tahun 1911. Lihat juga Alwi Shihab, Membendang Arus, Respons Geratan Mubammadijah Terhadap Penetrasi Misi Kristen di Indonesia, (Bandung: Mizan, 1998), hal. 105.

4 Abd. Al-Fattah Ahmad Fuad, Ibn Taimiyah Wa Mauqifuhu min al-Fikr al-Falsafah, (Kairo: 1980), hal. 234-235.

${ }^{5}$ Ibn Taimiyah, al-Furgon bayn Aulyo al-Rahman Wa aulya al-Syaithan, hal 70. Dan lihat pula, Ibid., hal 234.

${ }^{\circ}$ Taqiyuddin Ibn Taimiyah, Tasasuf dan Kritik terbadap Filsafat Tasaunf, (Kairo, 1986), hal. 22. 
(1058-1111 M) memberikan makna tasawuf dengan: "Ketulusan kepada Allah dan pergaulan yang baik kepada sesama manusia". Setiap orang yang tulus kepada Allah dan membaguskan pergaulan dengan sesama manusia menurut al-Ghazali disebut sufi. $^{7}$

Sedangkan ketulusan kepada Allah SWT. berarti menghilangkan kepentingankepentingan diri sendiri (bawa al-nafs) untuk melaksanakan

sepenuh hati. Sementara pergaulan yang baik dengan sesama manusia tidaklah mengutamakan kepentingannya di atas kepentingan orang lain, selama kepentingan mereka itu sesuai dengan syariat. Sebab, setiap orang yang rela terhadap penyimpangan syariat atau dia mengingkarinya, menurut al-Ghazali, dia bukanlah sufi. Jadi, sufi adalah orang yang menempuh jalan hidup dengan menjalankan syariat secara benar dan sekaligus mengambil spiritualitas (hakikat) dari ajaran syariat dalam bentuk penyucian dan pendekatan diri secara terus-menerus kepada Allah Swt. Perilaku ketaatan terhadap syariat itu kemudian diwujudkan dalam perilaku yang penuh moralitas (akhlak mulia) dalam kehidupan sehari-hari (tasawuf akblaqi).

Apabila pengertian tasawuf mengacu pada pencanderaan seperti yang diungkapkan oleh Ibn Taimiyah maupun al-Ghazali seperti yang disebutkan di atas, maka di dalam Muhammadiyah pun akan muncul wajah-wajah tasawuf, yakni mereka yang ketaatan serta kehidupan spiritualitasnya cukup intens. Tidaklah mengherankan bila disimak dengan seksama penuturan salah seorang murid K.H.A. Dahlan, yaitu K.R.H. Hadjid, bahwa di antara referensi pendiri Muhammadiyah adalah kitab-kitab yang ditulis oleh tokoh-tokoh seperti Ibnu Taimiyah, Ibn al-Qayyim, Muhammad ibn Abd al-Wahhab, Muhammad Abduh dan termasuk juga karya al-Ghazali Kitabkitab tasawuf seperti Ibyâ Ulûm al-Dín, Bidâyab al-Hidâyab, Kimiyab al-Sa'âdah, Kitab al-Arba'în fi Ushul al-Din dan sebagainya menjadi bacaan KHA. Dahlan, ${ }^{8}$ sehingga keakraban kehidupan spiritual yang dekat dengan wilayah tasawuf juga mewarnai kepribadian pendiri gerakan pembaruan dalam Islam ini. Bahkan beberapa penerusnya seperti $\mathrm{Ki}$ Bagus Hadikusumo, cukup intens dalam kehidupan wilayah ini (baca: bertasawuf). Dia menekankan pentingnya akhlak lubur dan kesederhanaan dalam hidup. Ia prihatin terhadap krisis akhlak yang melanda umat. Banyak orang

${ }^{7}$ Al-Imam al-Ghazali, al-Qowaid al-Ayyrab dari Majmu'ab al-Rasail, Juz 5 (Beirut, Dar al-Kutub alIlmiyyah, 1988), hal. 143-155.

${ }^{8}$ Muh. Djazman al-Kindi, "Gagasan dan Fikiran Ahmad Dahlan dalam" Almanak Mubammadiyah 1416 H (Yogyakarta, Majlis Pustaka PP. Muhammadiyah, 1995), hal. 210-211, Lihat juga Ahmad. Syafi'i Ma'arif, "Apa Literatur KHA. Dahlan" dalam Mubammadijah, Sejarab, Pemikiran dan Amal Usaba, (Yogyakarta, Tiara Wacana, 1990), hal. 25-30. 
mengaku Muslim (KTP-nya Islam), tetapi petilakunya tidak Islami. Terhadap krisis ini, Ki Bagus menulis tentang akhlak dalam bukunya Pustaka Ihsan yang mengemukakan tentang istiqâmab, tawakkul, mubâsabab, 'adl, sbidq, tawâdhu', ikhlâs, amânah, shabr serta qanâ'ab.'

Sementara itu, figur A.R. Fakhruddin juga pantas masuk dalam kategori sebagai sosok sufi dalam Muhammadiyah. Katena menurut hemat penulis, ia dapat mewakili wajah kehidupan spiritualitas dalam Muhammadiyah, karena beberapa alasan. Pertama, praktik hidup pribadi A.R. Fakhruddin mencerminkan perilaku kehidupan spiritual yang sangat dekat dengan wilayah tasawuf. Hal ini dapat dilihat, misalnya, dalam kehidupannya sehari-hari, baik ketika bertugas, di lingkungan rumah tangganya, di masyarakat maupun di kalangan organisasi Muhammadiyah yang dipimpinnya, ia senantiasa mencerminkan pribadi mutasawwif dan watak tasawuf yang akhlaqi, mementingkan pembinaan dan pengamalan perilaku yang menunjukkan akhlak mulia.

Kehidupannya mencerminkan hidup dan kehidupan yang sederhana, asketik dan tidak ngoyo (zâbid). Ia senantiasa menekankan pada perilaku akhlak terpuji. Dalam salah satu ceramah A.R. Fakhruddin, Nakamura pernah mengutip inti ceramahnya sebagai berikut: ${ }^{10}$

"Bahwa kita dapat berdoa lima kali sehari dengan teratur, namun jika akblak kita tetap buruk, tetap rakus, kikir, tidak mau memperhatikan yang miskin dan susah, maka doa kita tidak akan diterima oleh Allah, tidak akan masuk surga, namun bahkan masuk neraka. Kita dapat menyelesaikan puasa, namun jika kita tetap membicarakan keburukan orang lain, berdusta, menipu, sombong, maka puasa kita tidak berguna dan tidak diakui oleh Allah, marilah kita berdo'a, berpuasa, berhaji, membayar zakat, dan di atas segalanya ini, marilah kita memperbaiki akhlak kita".

\section{Selanjutnya A.R. Fakhruddin menambahkan:}

"Bahwa jalan yang paling pasti untuk membentuk akhlak yang mulia adalah melakukan ibadat, dengan kesadaran penuh kepada Tauhid. Jalan yang harus dilalui dengan kesadaran adalah hastat seseorang untuk menjadi ikhlas. Ikhlas menunjuk kepada orientasi mental yang sepenuhnya tidak terikat pada hal-hal yang bersifat duniawi, kosong, bersih, dan kekosongan inilah yang harus difsi dengan Allah sepenuhnya diisi dengan kebaktian kepada Allah, tidak pada yang lain. Bahwa shalatshalat sunnah, termasuk witir, shalat dhuha dan yang sejenisnya sangatlah dianjurkan.

'Farid Ma'ruf, Analisis Akblak dalam Perkembangan Mubammadyyab, (Yogyakatta, Majlis Tabligh, PDM, 1990), hal. 24-31.

63.

${ }^{10}$ Mitsuo Nakamum, Agama dan Lingkungan Kulturdl Indonesia (Surakarta, Hapsara, 1983), hal. 62- 
Dan bahwa dzikir, wirid, bukanlah monopoli taretkat, dan boleh diperaktikkan bilamana hal tersebut dapat membantu meningkatkan kesalehan seseorang serta ikhlas dalam beribadah maupun dalam bermu'amalah".

Dalam tindakan dan perbuatannya, A.R. Fakhruddin dapat dicandera lebih mencerminkan pribadi "ama", figur yang menekankan pada perbuatan nyata, aksis sosial kemanusiaan. Baginya yang penting adalah bagaimana Islam benar-benar dapat diamalkan dalam kehidupan sehari-hari. Kepuasannya yang mendalam adalah bilamana umat Islam sungguh-sungguh dapat mencerminkan dirinya sebagai muslim yang baik, Muslim dalam keyakinan, dalam ucapan maupun dalam tindakannya. ${ }^{11}$

Di antara watak muslim "amal" ini agaknya lebih dekat kepada wilayah tasawuf, dibandingkan muslim "intelektual" yang mungkin lebih dekat kepada wilayah kalam atau filsafat.

Kedua, karya-karya tulisnya, jelas memang diungkapkan dengan narasi yang berbeda dengan karya al-Ghazali maupun Ibn Taimiyah, namun substansinya senafas dengan karya-karya tasawuf al-Ghazali, misalnya tentang $A d a b$-adab dalam Beragama, tentang al-Qawâiid al-Asyrah, Tindak Kepatuban, Menghindar dari Dosa, baik dosa-dosa tubuh maupun dosa-dosa jiwa yang berhubungan dengan Allah Swt dan manusia, tentang taubid, iman, penyucian dini dari noda, dosa, maksiat, dan lain sebagainya.

Gaya penulisannya sederhana, namun menarik dan enak dibaca. Sepintas, karena kesederhanaannya, terkesan seolah-olah kurang dilandasi teori-teori yang dapat mencerminkan sebagai tokoh pergerakan modernisme dalam Islam. Padahal, justru di situlah letak kekuatannya. Sebab, apa yang dikemukakan dan ditulisnya merupakan manifestasi dari kedalaman dan pengamalan Islam yang diyakininya serta bertolak dari kejujuran dan ketulusan pribadinya, pengalaman keseharian dan problem-problem aktual keagamaan dan kemasyarakatan yang ditemuinya. Dengan

"Semangat itu barangkali diilhami oleh Muhammad Abduh yang pemah berefleksi, bahwa ketika di Paris Perancis, ia banyak menjumpai Islam diamalkan oleh Barat dalam berbagai aspek kehidupan (Kota Paris kenang Abduh saat itu terkenal bersih, indah, nyaman, aman, tertib, dan penuh peradaban); meskipun tidak banyak menjumpai orang-orang Islam. Sebaliknya, ketika berada di Kairo-Mesir, ia banyak menjumpai orang-orang Islam, tetapi ajaran Islam nyaris tidak banyak ditemui dalam perilaku nyata. Jadi, yang perlu ditekankan adalah al-amal al-Islami (perilaku/aksi Islami). Karena itulah, abduh berpendapat bahwa al-Islam mabjub bi al-muslimin (Islam itu mundur, terbelakang, bodoh, miskin, dsb. Karena perilaku orang-orang Islam itu sendiri yang tidak Islami). Jadi, yang mundur bukan Islamnya, melainkan para pemeluk Islam itu sendiri yang tidak memahami dan mengamalkan ajaran Islam yang bervisi bukan Islamnya, melainkan para pemeluk Islam itu senditi yang tidak memahami dan mengamalkan ajaran Islam yang bervisi bukan Islamnya, melainkan para pemeluk Islam itu sendiri yang tidak memahami dan mengamalkan ajaran Islam yang bervisi kemajuan. 
karya-karyanya dalam bentuk tadqkirab (peringatan/pelajaran moral) dan anekdotis, di sana dapat dibaca bahwa sifat-sifat dan pribadinya sendiri adalah karya-karya tulisnya itu.

Ketiga, A.R. Fakhruddin adalah pimpinan puncak di Muhammadiyah (Ketua Pimpinan Pusat Muhammadiyah) terlama sepanjang sejarah perkembangannya, yaitu selama 22 tahun (1968-1990), sementata pendiri Muhammadiyah sendiri yakni K.H.A. Dahlan memimpin Muhammadiyah selama 11 tahun (1912-1923). Bahkan sebelum dipilih sebagai Ketua PP Muhammadiyah, cukup lama A.R. Fakhruddin menjadi pimpinan di daerah dan tingkat wilayah, dan selama 30 tahun diberi tugas oleh pengurus besat Muhammadiyah untuk menggerakkan dakwah di pelosok Sumatera Bagian Selatan.

Dengan demikian, A.R. Fakhruddin memiliki kesempatan yang cukup untuk memberi corak kehidupan yang bernuansa tasawuf dalam kepemimpinan dan kehidupan gerakan Muhammadiyah. Selama periode tersebut, melalui kepemimpinannya di tingkat nasional, betbagai kegiatan dan pertemuan, baik di tingkat pusat, wilayah, daerah, cabang maupun di tingkat ranting dapat dilakukan secara intensif dan cukup padat. Bahkan ia seringkali mengisi balagab-halaqab (pengajian-pengajian dalam forum-forum terbatas) di lingkungan keluarga besar Muhammadiyah, seperti jamaah wanita, 'Aisyiyah, Nasyi'atul 'Aisyiyah, remaja, kaum terpelajar, guru-guru dan dalam berbagai komunitas lainnya.

A.R. Fakhruddin adalah simbol dan lambang kepemimpinan Muhammadiyah, menjadi tipe pengembangan kepribadian Muhammadiyah dan tokoh sentral yang lengser dari puncak piramida persyarikatan secara ikblas dan legouso. Ia telah bertiwikrama menjadi trade mark organisasi Islam yang paling rapih di Indonesia. Semua itu, secara langsung ataupun tidak, dapat memberi pengaruh dalam kehidupan persyarikatan. Didukung pula oleh hampir semua karya tulisnya yang lebih banyak ditujukan kepada pembaca keluarga persyarikatan, seperti: Pedoman Muballigh Mubammadiyab, Pedoman Anggota Mubammadiyah, Mubammadiyab Abad XV H, Kepribadian Mubammadiyah, Pemimpin Muhammadiyab dan beberapa karya lain dalam bentuk tanya jawab, artikel di majalah Suara Muhammadiyah dan Suara Aisyiyah, serta makalahmakalah yang disampaikan pada balaqab-balaqab, penataran, seminar baik untuk anggota, pengurus, maupun kader-kader Muhammadiyah, selurubnya cukup efektif dalam kurun yang demikian relatif panjang dalam memberikan sentuhan tasawuf dari pancaran pribadinya dalam jiwa dan amalan anggota Muhammadiyah. 
Tema-tema majelis balagah, tabligh, pengajian, kuliah, khotbah, ataupun tulisan-. tulisan yang tersebar dalam brosur dan majalah-majalah intern persyarikatan Muhammadiyah, memang tidak mengangkat tema yang secara eksplisit tentang tasawuf, seperti tokoh lain dalam Muhammadiyah, yaitu Bụya Hamka, namun sarat dengan pelajaran akhlaq yang dekat dengan wilayah tasawuf, yaitu tasawuf akhlaqi. Sementara karya-karya Hamka di bidang tasawuf, lebih bersifat universal dan ditujukan untuk khalayak pembaca yang beragam, karya-karyanya antara lain Tasavvif Modern; Tasawuf, Perkembangan dan Pemurniannya; Renungan Tasawuf, Lembaga Budi dan Falsafab Budi.

Tanpa menyebut kata tasawuf sebenarnya A.R. Fakhruddin telah mempraktikkan dan menyebatkan ajaran akhlak tasawuf secara inklusif. Waktu yang dimiliki selama menjadi tokoh puncak Muhammadiyah, memberi peluang yang cukup luas untuk mensosialisasikan pikiran/renungan dan seruan-seruannya baik dalam perilaku organisasi maupun praktik pribadi dalam mengamalkan ajaran Islam yang bernuansa tasawuf. Jiwa dan pribadinya merentang cermin pribadi "suf" dalam hal taubat, takun, wara, zubd, mjâ, khauf, kbuxyu', tawvâdbu', qanâah, tavvakeul, svukr, shabr, vidhâ, istiqâmah, ikhlâr, dan bebempa tahapan lain penempuh jalan sufi seperti pencanderaan Imam al-Qusyairi di dalam Risâlab al-Qusyairiyab. ${ }^{12}$

Menurut hemat penulis, kehidupan spiritual A.R. Fakhtuddin dapat digolongkan dalam pribadi yang hidup berdasarkan pencerahan dan memiliki karakter tasawuf (tasawuf akhlaqi), serta menjadi salah satu tokoh puncak dan panutan di dalam komunitas persyarikatan Muhammadiyah yang menghayati dan "berjiwa sufi". Namun, asumsi sementara di atas perlu dibuktikan, apakah benat kehidupan spititual A.R. Fakhruddin itu memang memiliki karakter tasawuf yang dekat dengan dunia sufi? Lalu, cukup tepatkah pernyataan ini ditujukan kepada A.R. Fakhruddin? Bukankah karya-karya tulisnya juga tidak spesifik menulis tentang tasawuf, meskipun sarat dengan dimensi dan pelajaran akhlak?

\section{B. Permasalahan}

Bahasan dalam tulisan ini sesungguhnya bertolak dari suatu keinginan untuk memperoleh suatu jawaban yang pasti dari pertanyaan, apakah di dapur gerakan organisasi Muhammadiyah (melalui tokoh-tokohnya), terdapat perilaku kehidupan spiritual yang sudah sangat dekat dengan wilayah tasawuf? Pertanyaan ini muncul

${ }^{12}$ Abu al-Qasim Abd al-Karim al-Qusyairi, al-Risalah al-Qusyaimiah fi Ilm al-Tashaunvf, (Beirut, Dar al- Khair, t.t), hal. 171. 
karena selama ini gerakan Muhammadiyah dikenal sebagai pelopor gerakan pembaruan pemikiran Islam, yang lebih mengutamakan aspek tasional dalam beragama dan menekankan pentingnya peranan akal serta pendidikan akal, dibandingkan dengan kehidupan spiritual yang mengandalkan kepekaan hati dan intuisi.

Karena itu, tulisan ini berusaha menyuguhkan jawaban terhadap beberapa pertanyaan yang selama ini menggelitik penulis dan mungkin juga pembaca sebagai berikut:

1. Sejauh mana dan dalam batas-batas apa kehidupan spiritual A.R. Fakhruddin dalam kehidupan kesehariannya sehingga diasumsikan sudah mendekati wilayah tasawuf?

2. Dan jika benar, aliran tasawuf yang bagaimana yang diakrabi oleh A.R. Fakhruddin?

3. Apakah A.R. Fakhruddin juga memaparkan tenungan dan pemikirannya dalam bentuk karya tulis yang bercorak akhlak dan tasawuf?

4. Bagaimana pengaruh perilaku kehidupan spirttual A.R. Fakhruddin di kalangan komunitas jamaahnya yakni dalam spektrum Muhammadiyah?

Tulisan ini diharapkan dapat membuktikan bahwa di dapur gerakan organisasi modernis terbesar di dunia, meminjam ungkapan Nurcholish Madjid, Muhammadiyah yang notabene menamakan diri sebagai organisasi reformis dan gerakan pembaruan, ternyata tokoh-tokohnya, khususnya A.R. Fakhruddin, menjalankan kehidupan spiritual yang cukup intens dan akrab dengan wilayah tasawuf. Data dan sumber yang diharapkan dari tulisan ini adalah diperoleh, melalui observasi dan wawancara dengan keluarga serta kolega dan lain-lain dan dari berbagai tulisan A.R. Fakhruddin sendiri serta tulisan-tulisan dai tokoh lain yang relevan, dan dengan pendekatan kualitatif.

\section{Pembahasan}

\section{Dibesarkan dan Membesarkan Muhammadiyah}

Sejak kecil A.R. Fakhruddin ditempa dan dibesarkan di lingkungan Muhammadiyah. Bahkan, dapat dikatakan bahwa kehidupannya telah menyatu dengan Muhammadiyah. Semangatnya untuk terus belajar tidak pernah padam, meskipun dengan belajar mandiri, maupun dengan menimba ilmu dari para tokoh Muhammadiyah atau yang populer dengan sebutan al-Sâbiqûn al-Awvalûn seperti KH. Sudja, 
KH. Ahmad Badawi, KRH.. Hadjid, KH. Muchtar, Ki Bagus Hadikusumo, KH. Djohar, KH. Muslim, KH. Kanad, KH. Bakir Saleh, KH. Basyir Mahfudz, Hj. Badilah Zuber dan lain sebagainya. ${ }^{13}$

Tokoh-tokoh tersebut merupakan orang-orang yang telah menempa A.R. Fakhruddin dalam masalah-masalah keagamaan maupun kemuhammadiyahan. Mereka semua dianggap sebagai orangtua oleh A.R. Fakhruddin. Oleh karena itu, apapun yang diperintahkan oleh mereka dalam mengamalkan ilmu pengetahuan dan menyebarkan agama dilakukan oleh A.R. Fakhruddin. Berdakwah ke mana saja, atas perintah para seniornya dilakukannya dengan senang hati. Inilah kelak yang membesarkan namanya di kalangan Muhammadiyah.

Riwayat perjalanan karir A.R. Fakhruddin di Muhammadiyah dimulai dari grass root (tingkat paling bawah), yakni menjadi Pimpinan Ranting, Cabang, Daerah, Pimpinan Wilayah sampai dengan pimpinan pusat. Ia dapat menjadi pemimpin tingkat nasional setelah melalui proses yang amat panjang. Kepemimpinannya selama 22 tahun bukanlah waktu yang sebentar, dan ini membawa namanya ke puncak popularitas, tidak hanya di lingkungan Muhammadiyah, akan tetapi juga di pentas nasional dan masyarakat Indonesia. Keberhasilannya dalam berdakwah dan memimpin Muhammadiyah, banyak diakui oleh berbagai kalangan, baik kalangan Muhammadiyah sendiri, kalangan Muslim, maupun non-Muslim.

Wajarlah kalau dikatakan bahwa A.R. Fakhruddin adalah aset bangsa Indonesia. Seluruh waktu yang dimilikinya, dicurahkan untuk membesarkan Muhammadiyah. Untuk menjadi pemimpin yang baik, menurut A.R. Fakhruddin adalah pemimpin yang dapat menghayati bagaimana kehidupan umat secara tiil, bagaimana derita dan nestapa umat di tingkat bawah dan bagaimana kesulitan berdakwah dan menggerakkan organisasi di tingkat Ranting yang jauh dari kota, yang serba kekurangan sarana dan prasarana. Segala kesusahpayahan, kesulitan-kesulitan, dan suka duka seseorang bekerja di tingkat basis dapat memberi pengalaman yang berharga dan menjadikan seseorang menjadi lebih arif dalam mengambil kebijakan dan memimpin umat. ${ }^{14}$

A.R. Fakhruddin berobsesi untuk terus dapat membina pimpinan dan caloncalon pimpinan serta melakukan kaderisasi, sehingga kelak Muhammadiyah melahirkan serta memiliki pemimpin-pemimpin yang paham tentang Islam,

${ }^{13}$ Suratmin, Perikebidupan, Pengabdian dan Pemikiran Abdur Ratzag Fakbruddin dalam Mubámmadiyah, (Yogyakarta, Pustaka SM, 2000), hal. 5.

${ }^{14}$ Suara Muhammadiyah, Pikiran dan Tindakan Pak AR (Yogyakarta, Pustaka SM, 1995), hal. 6. 
menghayati ajaran Islam, memahami dasar dan cita-cita Muhammadiyah, menghayati dan memahami penderitaan umat dan kaum dhu'afa (kaum lemah dan tak berdaya). A.R. Fakhruddin mengangan-angankan para pemimpin Muhammadiyah yang berakhlak mulia, bijak, dan arif dalam mengambil setiap keputusan, tawâdbu' dalam setiap langkah dan tindakannya, sederhana dalam perikehidupannya, tamah dan merakyat dalam menghadapi umat dari kelas manapun mereka berasal. AR. Fakhruddin mencita-citakan para pemimpin Muhammadiyah yang berwawasan luas, berpandangan jauh ke depan, kreatif untuk menyelesaikan setiap masalah, dinamis dan inovatif sebagaimana dicontohkan oleh Rasulullah SAW.

Óbsesi A.R. Fakhruddin tersebut, sesungguhnya tidaklah berlebihan, karena hal itu semua sudah dicontohkan juga melalui dirinya. Ia merupakan contoh dari sikap hidup ber-Muhammadiyah yang tulus dan tak kenal lelah.

Haedar Nashir dalam salah satu tulisannya di Suara Mubanmadiyab mengatakan bahwa persyarikatan boleh berganti dan berubah-ubah, bumi dan matahari boleh gonjang-ganjing, pemimpin formal Muhammadiyah boleh berganti seribu satu kali, tetapi A.R. Fakhruddin tetap ber-Muhammadiyah dengan tulus dan bersahaja. Semua orang diajak untuk meraih kemudahan, dan tidak mempersulit sesuatu yang sebenamya mudah. Ia tidak membawa Muhammadiyah dengan kecut hati, garang, muka masam dan cemberut. ${ }^{15}$

Melalui perilaku inilah A.R. Fakhruddin membesarkan Muhammadiyah. Tidak dapat disangkal oleh siapapun dan pasti mengakui bahwa keberadaan A.R. Fakhruddin di pucuk pimpinan persyarikatan selama ini mempunyai andil yang tidak kecil dalam menggalang saling pengertian antara sesama umat Islam, antara umat Islam dengan pemerintah. Gaya kepemimpinannya yang lurus, bersih dan murni merupakan modal yang sangat bermanfaat dalam mencari penyelesaian berbagai petsoalan umat. Gaya dan canda segarnya mampu mencairkan suasana tegang di forum apapun yang dihadirinya. Gaya kepemimpinan seperti ini memang kadang dibutuhkan untuk situasi di mana kecurigaan seringkali mudah menjadi dalih mengambil suatu tindakan oleh mereka yang memiliki kekuasaan.

\section{Karya dan Dedikasinya}

Selaku pimpinan yang sudah banyak makan asam garam dalam Muhammadiyah, A.R. Fakhruddin merasa bertanggung jawab untuk terus memikirkan demi upaya

\footnotetext{
${ }^{15}$ Haedar Nashir, "Welas Asih dan Gembira dalam Muhammadiyah" dalam Suara Mubammadjyab (16-30 April, 1995), hal12.
} 
melestarikan, meningkatkan, dan memajukan organisasi yang cukup besar di Indonesia ini. Untuk keperluan tersebut dan dalam rangka pengabdiannya kepada Allah SWT., ia menuangkan pikiran-pikirannya melalui karya-karyanya baik yang berbentuk buku, monografi, kumpulan esai, atau tanya jawab yang kemudian dibukukan oleh murid-muridnya, maupun oleh AR. Fakhruddin sendiri. Pemikirannya pada umumnya dituangkan dalam tiga masalah pokok, yakni masalah keagamaan, masalah persyarikatan dan masalah kemasyarakatan. Ketiga masalah ini merupakan kesatuan yang utuh. Di antara buah pikiran serta karyanya, dapat dilihat misalnya:

1. Memelibara Rub Muhammadiyah, yang diterbitkan pada tahun 1996.

Buku ini merupakan kumpulan dari tulisan-tulisan pendeknya, yang isinya antara lain tentang: pengembangan ibadah sosial keagamaan dan sosial kemasyarakatan, tabligh Muhammadiyah adalah tabligh Islam, mempetbaharui niat, pesan kepada para mahasiswa, jangan berebut jadi pemimpin, ruh musyawarah dalam Muhammadiyah, beribadah menurut tuntunan Rasulullah, dan lainnya.

Dalam salah satu judul dari tulisannya tersebut yakni: Yang Berbak Memimpin Muhammadiyah, penulisnya menekankan tentang akhlak utama Islami, mencontoh perilaku Rasul. Sebagai seorang pemimpin harus mampu menjadi teladan dan uswah hasanah bagi pengikutnya khususnya dalam beramal dengan penuh keikhlasan semata karena Allah, ber-tagarrub kepada Allah dengan kbusyu', tawâdhu dan penuh rasa kbasyyab (takut akan kebesaran Allah) serta taquallab, dan lain sebagainya. Demikian anjutan moral yang bernuansa sufistik dari penulisnya.

\section{Muhammadiyab Abad XV Hijriyah, terbitan tahun 1985.}

Buku ini berisi serangkaian wacana pendek yang pada awalnya berjudul Mubammadiyab Tujub Pulub Langkab Ke Depan, sebuah brosur yang disiapkan sebagai panduan bagi para warga dan pimpinan Muhammadiyah yang sarat dengan pesan moral. Penulisnya mengajak dan menekankan kepada seluruh warga dan pengurus Muhammadiyah agar berakhlak mulia, berbudi pekerti yang luhur. Yang dimaksud budi pekerti yang luhur antara lain misalnya ramah jika bergaul, tidak menyakitkan hati jika bicara, suka menolong sesama, tidak dusta dan bohong, tidak dengki dan khianat, tidak bakhil tetapi membela yang tertindas, semua itu adalah budi pekerti yang luhur. Pokok-pokok budi pekerti luhur menurutnya adalah yakin adanya Allah, yakin bahwa Allah Maha Kuasa, Maha Esa, Maha Tahu, Maha Bijaksana dan Maha Sempurna. Karena itu, sumber dari budi pekerti luhur adalah berbakti kepada Allah, 
mentaati perintah-Nya dan menjauhi larangan-Nya. A.R. Fakhruddin melihat bahwa antara keimanan dan akhlakul karimah seiring dan sejalan.

3. Soal Jawab yang Ringan Ringan, yang diterbitkan pada tahun 1990.

Buku ini merupakan jawaban, untuk memenuhi permintaan dari berbagai kalangan dari acara "Soal Jawab" yang disiarkan oleh RRI Nusantara II Yogyakarta, yang dilakukan oleh A.R. Fakhruddin bersama-sama dengan Muchlas Abrar dari kantot Wilayah Departemen Agama Daemh Istimewa Yogyakarta. Kumpulan soal jawab ini berisi masalah-masalah yang betkisar pada masalah aqidah, akhlak, ibadah dan muamalah, baik muamalah terhadap Allah maupun kepada sesama manusia. Yang menarik dari buku ini, ketika A.R. Fakhruddin menjelaskan tentang Kitab al$A d z^{k} a ̂ r$ ia menganjurkan agar menghafal doa-doa tertentu, serta mengucapkan kalimah la Ilâba illa Allab seratus kali dan subbânallah seratus kali sebagaimana hadis Nabi yang dikutipnya sebagai berikut: "Barang siapa mengucapkan kalimah la Ilâha illa Allab sehari seratus kali, sama dengan memerdekakan sepuluh hamba sahaya. Baginya ditulis (mendapatkan) seratus kebajikan, diampuni seratus kesalahan dan menjadi benteng dari godaan setan pada hari itu sampai sote hari. Dan tidak ada seorangpun yang mendapatkan keutamaan lebih dari itu kecuali bagi yang membacanya lebih dari itu"." 16

A.R. Fakhruddin mengutip hadis Nabi Saw. sebagaimana yang diriwayatkan oleh al-Bukharî dan Muslim dari Abu Hurairah, bahwa Rasulullah Saw. bersabda: "Barang siapa mengucapkan subhânallab wa bi bamdibi seratus kali dalam satu hati, maka diampuni kesalahannya meskipun seperti buih banyaknya"."7

Dzikir, wirid, dan doa yang disertai dengan jumlah bilangan tertentu memang acapkali dianjurkan oleh A.R. Fakhruddin, selama dzikir dan wirid itu membantu pelakunya memperoleh ketenangan jiwa dan ketenteraman batin. Dalam hal ini, Allah berfirman: "Ketahrilab, dengan mengingat Allah, hati menjadi tenteram nan damai..." (QS. al-Ra'd [13]: 28). A.R. Fakhruddin menyadari betul keterbatasan dan kelemahan manusia, kalau saja ia tidak menyandarkan diri kepada Sang Khaliq, melalui berdzikir dan memohon pertolongan kepada-Nya, maka, ia bisa jadi mudah putus asa, dan bahkan amalnya jauh dati keikhlasan. Bukankah setiap kali seorang muslim melaksanakan shalat selalu berikrar dan berkomitmen untuk hanya beribadah dan memohon pertolongan kepada Allah semata (QS. al-Fâtihah [1]: 5)?

${ }^{16}$ A.R. Fahruddin, Soal Jasvab yang Ringan-Ringan (Yogyakarta, tp, 1990), hal. 22.

${ }^{17}$ Ibid 
Dzikir, wirid, maupun doa yang dianjurkan oleh A.R. Fakhruddin sebagaimana yang ditulisnya dalam bab Kitâb al-Adzkâr yang pada umumnya dilandasi oleh ayatayat al-Qur'an dan Hadis, antara lain dapat penulis kutipkan seperti berikut ini:

1. Diriwayatkan oleh al-Bukhari dan Muslim dari Abu Hurairah, bahwa Rasulullah Saw. bersabda: "Dua kalimat yang ringan diucapkan, tetapi mempunyai bobot yang betat dalam timbangan di akhirat kelak" adalah:

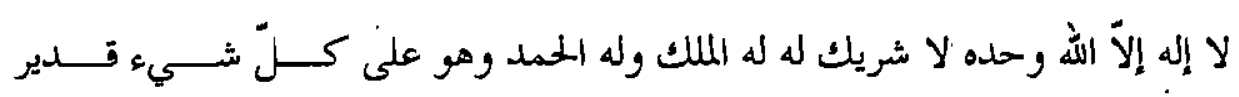

2. Dari Tsaubân r.a. berkata, Rasulullah SAW. setelah selesai shalat kemudian membaca istigffär (memohon ampun) tiga kali, kemudian membaca:

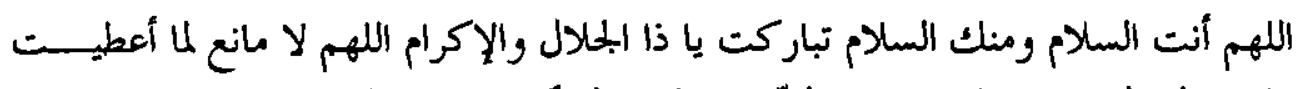

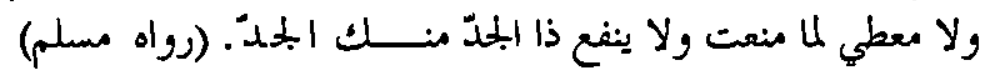

3. Dari Mughîtah ibn Syu'bah r.a. sungguh Rasulullah SAW. apabila telah selesai shalat kemudian membaca:

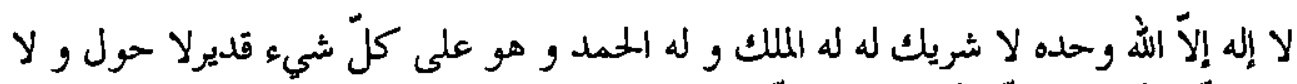

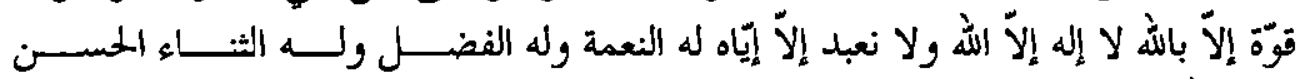

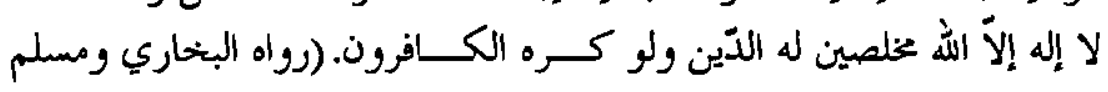

4. Dari Abu Sa'id al-Khudri berkata, Rasulullah SAW. bersabda: "Perkataan yang selalu baik yaitu ucapan":

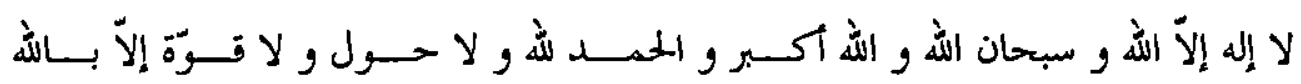

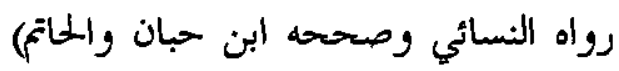

5. Dari sahabat Anas ra. berkata: "Sebanyak-banyak doa yang dibaca oleh Rasulullah SAW. ialah":

ربنّا آتنا في الدّنيا حسنة و في الآنهرة حسنة و قنا عذاب النّار (رواه البخاري ومسلهم)

6. Dari Abu Hurairah r.a. berkata, Rasulullah Saw. bersabda:

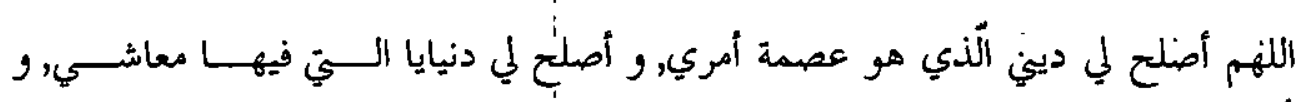

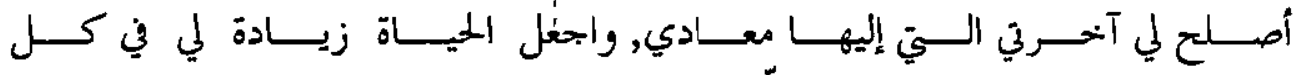

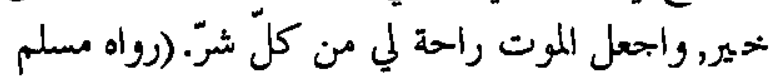


"Ya Allah, baguskanlah bagiku agamaku yang menjadi sumber segala perkaraku. Dan baguskanlah duniaku yang menjadi sumber penghidupanku. Dan baguskanlah akhiratku yang menjadi tempat kembaliku. Jadikanlah perjalanan hidupku tambahan segala kebaikanku. Dan jadikanlah matiku sebagai pelepasan dari segala kejahatankejahatan."

Buku ini juga memuat beberapa judul pantun, yang isinya tentang akhlak, syukr, tawâadhu', sbidq, ikhlâs, ridhâ, juga pantun kematian, ukhuwwah Islamiyah dan lainnya. Pantun yang cukup bernuansa tasawuf dan akblak. Mencermati buku ini, AR. Fakhruddin juga menekankan pada bilangan tertentu, baik dalam dzikir, wirid dan doa. Suatu kelaziman yang dilakukan dalam dunia tasawuf dan tarekat. Tentu tujuannya jelas, sebagaimana yang dikatakannya; selama membantu pelakunya memperoleh ketenangan jiwa dan ketentraman batin, mengapa tidak?

Selain tiga buku yang disebutkan di atas, masih banyak lagi buku-buku lain yang tidak dapat diangkat pada tulisan singkat ini. Bahkan menurut sumber yang dapat dipercaya, masih banyak tulisan-tulisannya yang tercecer, yang hingga saat ini belum dapat dihimpun. Karya-karyanya sarat dengan pesan moral dan akhlak. Dengan demikian semakin memperkuat asumsi penulis, bahwa AR. Fakhruddin, memang dapat dikategorikan sebagai seorang zahid (hidup sederhana), mukblish (beribadah dan berkarya dengan penuh keikhlasan) dan ini mendekati wilayah sufi akhlaqi.

\section{Esensi Bertasawuf}

Dimensi akhlak pada pribadi A.R. Fakhruddin yang berupa sifat-sifat terpuji yang merupakan untaian perbuatan hati dan kadang disebut maqâm (station, tahapan) dan abyaal (kondisi spiritual), dalam tasawuf, nampaknya suatu ciri khas dalata diri A.R. Fakhruddin. Antara akhlak dengan tasawuf (baca: tasawuf praktis/kehidupan spirituai), sesungguhnya tidak terlalu jauh berbeda. Perbedaan mendasar kedua istilah tersebut barangkali dapat dirumuskan seperti berikut:

1. Bahwa tasawuf praktis/kecerdasan spiritual memiliki perangkat metodologis yang lebih memungkinkan bagi perbaikan akhlak.

2. Prinsip-prinsip akhlak le iih bersifat statis, sementara metode sayr wa suluk (penempuh jalan ruhani) bersifat dinamis.

3. Dalam tinjauan akhlak, jiwa manusia lebih dipandang sebagai tempat yang hatus dihiasi dengan dekorasi/hiasan akhlak-akhlak mulia, seperti; shabr, syukr, jujur dan sebagainya, maka di mata kaum sufi, jiwa manusia dipandang sebagai organisme yang hidup, yang tumbuh menuju kedewasaan melalui perjalanan ruhani. 
4. Penghiasan jiwa dalam tinjauan akhlak, dapat dilakukan secara acak dan sama sekali tidak berurutan, misalnya dapat dimulai dengan sifat kedermawanan dan seterusnya, maka di dalam tasawuf, maqâmat yang harus ditempuh setahap demi setahap dan kontinyu serta terstruktur misalnya dari maqâm taubat ke maqâmmaqâm berikutnya yang masing-masing magâm ditempuh sampai akhir perjalanan spiritual.

5. Ilmu akhlak lebih mengurusi pada hubungan dan pertanggungjawaban antara manusia dengan dirinya, dengan alam dan dengan Tuhan, maka dalam tasawuf untuk tahap awalnya lebih memfokuskan diri pada hubungan manusia dengan Tuhan. Hal ini karena tasawuf percaya bahwa hubungan manusia dengan Tuhan merupakan sumber akhlak yang paling sentral. ${ }^{18}$

Karena itu, penulis melihat bahwa spiritualitas atau kecerdasan spiritual seseorang terwujud karena ia lebih memfokuskan diringa pada hubungan dengan Tuhan. Jika meminjam istilah Junaid (seorang tokoh Sufi yang pandangannya jauh lebih keras dari Ibn Taimiyah), menurutnya tasawuf atau kehidupan spiritual adalah: "Engkau bersama Allah tanpa ada perantara apapun". Jadi, hakikat tasawuf menurut Junaid adalah bahwa kita selahu ingat atau bersama Allah dimanapun dan kapanpun.

Untuk selalu bersama Allah, maka perlu latihan ruhani yang tujuannya adalah meneladani akhlak Allah, hal ini sesuai dengan sabda Rasulullah SAW: تخلََـوا بـأخلاق "Berakhlaklah kamu dengan akhlak Allah". Jika seseorang benar-benar telah berhubungan baik dengan Tuhan, maksudnya bertauhid yang lurus dan istigâmab, maka dengan sendirinya ia akan meneladani perbuatan baik Tuhan dan dari sini muncul akhlak baiknya kepada sesama.

A.R. Fakhruddin sebagai seorang pribadi yang kehidupannya mendekati kehidupan spiritual pata sufi adalah seorang tokoh yang memang sebagian besar hidupnya dikhidmadkan untuk kemanusiaan, dalam rangka beribadah kepada Allah. Hal ini dapat dilihat misalnya dalam kehidupan kesehariannya, baik ketika bertugas, di lingkungan keluarganya, dalam masyarakat maupun di tengah-tengah warga Muhammadiyah. Ia senantiasa mencerminkan pribadi mutasaumif. Jiwa dan pribadinya mencerminkan pribadi yang kecerdasan spiritualitasnya cukup menonjol seperti dalam bâl: taubat, taqarrub, taquâ, dziker, kbusyu', tawâdbu', kbauf, rajâ, murâqabab, dan istiqâmah dalam rangka ittibâ' (mengikuti dengan dilandasi p̈engètahuan yang benat)

${ }^{18}$ Disarikan dari Tasanuf Tanpa Tarkeat karya Ramli Bihar Anwar, 2002, hal. 3-13, dan Tasawuf Antara Agama dan Filsofor oleb Ibrabim Hilal don Mgimu Fotana, Kitab Im al-Suluk Oleh Ibn Taimiyah. 
sunnah Rasul. Pandangan dan cara hidup A.R. Fakhruddin dapat digolongkan dalam pribadi yang hidup berdasarkan pencerahan dan karakter tasawuf. Di kalangan para tokoh sufi maqâm-maqâm atau manzilah-manzilab seperti yang disebut di atas adalah merupakan magâm-maqâm atau manzilah-manzilab yang masuk dalam kategori tasawuf akhlaqi.

Sementara, penulis melihat bahwa maqâm-maqâm: taubat, tagarrub, taqwâ, dqikr, kbusyu', tawâdbu', kbauf, rajâ, murâqabah dan istiqámab cenderung lebih tepat jika dikelompokkan ke dalam perilaku spiritual, karena bagaimanapun A.R. Fakhruddin lebih memfokuskan diri pada hubungan dengan Tuhan. Hubungan itu juga bersifat kontinyu serta tetap merupakan sumber akhlak yang paling sentral yang kelak memunculkan perilaku terpuji dan patut diteladani.

\section{Penutup}

Dari uraian di atas, penulis merasa perlu membuat catatan-catatan simpul sebagai epilog sebagai berikut:

1. A.R. Fakhruddin adalah seorang tokoh puncak pimpinan Muhammadiyah yang senantiasa menekankan dan mengamalkan perilaku al-akblâq al-karimah dalam setiap ucapan, tindakan serta perbuatannya. Dimensi akhlak yang menjadi "trade mark" atau yang menjadi milik A.R. Fakhruddin adalah sifat-sifat seperti: shabr, syukr, wara', zubd, qanâ'áb, tawakkul, ikblâsh, ridhâ dan lain sebagainya. Sifat-sifat ini sangat dominan tercermin dalam dirinya melalui perilaku kehidupan kesehariannya, seiring dengan ajakannya untuk dakwah Islam amar makruf dan nahi munkar yang disertai dengan teladan akhlak Rasulullah SAW. Sementara itu, kehidupan spiritual yang mengukir sebagian besar kehidupan A.R. Fakhruddin yang mencerminkan perilaku akhlak tasawuf dan kehidupan seorang sufi dapat tercermin dari perilaku dan pemikirannya tentang taubat, taqarrub (mendekatkan diri sedekat-dekatnya) kepada Allah, taquâ, dqikrullah, kbusyu', tawâdhu', khauf, rajâ, murâqabab serta istigâmah. Dari kehidupan spiritual yang telah dilewatinya atau yang telah dilakukannya seperti yang disebutkan, sesungguhnya A.R. Fakhtuddin sudah mendekati pada wilayah tasawuf. Andaikata ia tidak dapat dikategorikan sebagai seorang sufi (karena pengertian sufi yang disepakati secara umum adalah mereka yang berperilaku tasawuf akhlaki dan falsafati), maka tokoh A.R. Fakhruddin ini dapat dikatakan sebagai: كـاد أن يكـون مسوفيا (hampir mendekati tasawuf atau sudah dekat dengan predikat sufi). Dan jika istilah ini tepat, maka penulis menempatkan tokoh ini pada posisi "Sufi Akhlaqi". 
2. Praktik hidup A.R. Fakhruddin yang mencerminkan perilaku akhlak dan tasawuf, berdimensi sosial, harakah dan dakwah. Dalam setiap dakwahnya, baik tulisan maupun lisan tercermin ungkapan kisah hidup dan kiprahnya yang sangat peduli terhadap umat, bangsa dan negara. Ajakannya untuk selalu konsisten dan istiqâmah serta tetap betpedoman pada Kitabullab dan Sunnah Rasul membawa pada barakah (gerakan) yang nyata. Katena inilah inti Muhammadiyah sebagai organisasi gerakan (harakah), jam' 'yab dan persyarikatan, yang berdasarkan pada tauhid yang menjadi sumber dan basis kehidupan Muhammadiyah. A.R. Fakhruddin adalah tokoh Muhammadiyah / tokoh Islam yang patut dijadikan teladan dalam hal "berakhlak al-karimah".

3. Renungan dan pemikitan A.R. Fakhruddin yang dituangkan dalam bentuk karya tulisnya, memang tidak mengangkat tema yang secara eksplisit tentang tasawuf seperti tokoh lain dalam Muhammadiyah seperti Buya Hamka atau lainnya, namun sesungguhnya sarat dengan pelajaran akhlak yang sangat dekat dengan wilayah tasawuf, dalam hal ini tasawuf akhlaki Tanpa menyebut kata tasawuf, sebenarnya ia telah mempraktikkan dan menyebarkan contoh akhlak dan perilaku tasawuf secata inklusif. Waktu yang dimiliki selama menjadi tokoh puncak Muhammadiyah, memberi peluang yang cukup luas untuk mensosialisasikan pikiran/renungan dan seruan-seruannya baik dalam perilaku organisasi, maupun praktik pribadi dalam mengamalkan ajatan Islam yang bernuansa akhlak dan tasawuf. Jiwa dan pribadinya merentang cermin pribadi sufi (baca: sufi akhlaqi) dalam hal wara', zubd, taqwâ serta beberapa tahapan lain penempuh jalan suff.

4. Kehidupan spiritual A.R. Fakhruddin dapat digolongkan dalam pribadi yang hidup berdasarkan pencerahan dan memiliki karakter tasawuf (tasawuf akhlaqi), serta menjadi salah satu tokoh puncak dan panutan di dalam komunitas persyarikatan Muhammadiyah yang menghayati dan berjiwa sufi akhlaqi. Dengan karakter ini, secara langsung ataupun tidak, dapat memberi pengaruh dalam kehidupan persyarikatan. Didukung pula oleh waktu yang cukup panjang serta karya tulisnya yang lebih banyak ditujukan kepada pembaca keluarga petsyarikatan, seluruhnya cukup efektif dalam memberikan sentuhan "akhlak tasawuf" dari pancaran pribadinya dalam jiwa dan amalan anggota. 


\section{DAFTAR PUSTAKA}

Abdullah, M. Amin. 'Muhammadiyah dan Pemikiran Keagamaan, dalam Mubammadiyab Menyongsong Abad 21.

Al-Gazzaali. 1998. al-Qawaid al-Asyrab dari Majmu'ah al-Rasail, Beirut: Dar al-Kutub al-Ilmiyah.

Al-Hujwiti. 1974. Kasyf al-Mabjub, Kaito: Dar al-Turats.

Ali, Mukti. 1985. Interpretasi Amalan Muhammadiyah, Jakarta, Harapan Melati.

Al-Kindi, Muh. Djazman. 1995. Gagasan dan Fikiran Abmad Dablan dalam Almanak Muhammadiyah, Yogyakarta: Majelis Pustaka PP. Muhammadiyah.

al-Qusyairi, Abu al-Qasim Abd al-Karim. T.t. al-Risalab al-Qusyairiyab Fi Ilm alTashawnuf, Beirut: Dat al-Khair.

al-Syirbashi, Ahmad. 1970. Rasyid Ridha Shahib al-Manar, Kairo: tp.

Fakhruddin, A.R. 1982. Mikul D buwur Mendem Jero, Yogyakarta.

. 1983. Pancasila Kabeberaken, Agama Islam Kawedharaken, Yogyakarta.

1985. Muballigh Mubammadiyah, Yogyakarta.

. 1985. Mubammadiyab Abad XV Hijriyah, Yogyakarta.

- 1985. Tiga Pulub Pedoman Anggota Mrbammadiyah, Yogyakarta.

1989. Mubammadiyab Menjelang Muktamar ke-42 di Yogyakarta, Yogyakarta.

. 1990. Pak AR Menjawab, Yogyakarta.

1990. Selamat Tabun Baru, Yogyakarta.

. 1990. Soal Jawab Entheng-Enthengan, Yogyakarta.

1990. Soal Jawab yang Ringan-Ringan, Yogyakarta.

. 1992. Tuntunan Shalat Menurut Cara Rasulullab Saw, Yogyakarta.

1994. Menyongsong sidang Tanvir Mubammadiyab di Solo, Yogyakarta: t.p.

- 1995. Mengenang Pak AR, Yogyakarta.

. 1995. Pedoman Anggota Mubammadiyah, Yogyakarta.

1996. Memelibara Ruh Mubammadiyab, Yogyakarta.

. T.t. Abad XV Hijriah, Abad Kerukunan dan Kemajuan, Yogyakarta.

. T.t. Mubammadiyah adalab Organisasi Dakwab Islamiyah, Yogyakarta. 
. T.t. Muhammadiyah, Halal Bi Halal dan Keprihatinan, Yogyakarta. - T.t. Peringatan Maulid Nabi Besar Mubammad Saw, Yogyakarta.

. T.t. Piliblab Pimpinan Muhammadiyab yang Tepat, Yogyakarta.

Fu'ad, Abd. Al-Fattah Ahmad. 1980. Ibn Taimiyal wa Mauqifubu min al-Fikr alFalsafati, Kairo.

Hadjid, Kiyai. 1968. Ajaran KHLA. Dablan dengan 17 Kelompok Ayat-ayat al-Quran.

Kahin, Nationalism and Revolution in Indonesia.

Kusumo, Djarnawi Hadi. T.t. Matahari-Matabari Mubammadiyah, Yogyakarta: Persatuan.

Ma'arif, A. Syafi'i. 1996. Dinamika Pemikiran Islam dan Mubammadijah, Yogyakarta: Pustaka Pelajar Offset. . 1990. Apa Literatur KHA. Dablan dalam Mubammadijah, Sejarab, Pemikiran dan Amal Usaba, Yogyakarta: Tiara Wacana.

Ma'ruf, Farid. 1990. Analisis Akhlak Dalam Perkembangan Mubammadiyah, Yogyakarta: Majlis Tabligh, PDM.

Mughni, Syafiq A. 1998. Muhammadiyab dan Pemikiran Keagamaan dalam Muhammadiyab Menyonsong Abad 21, Yogyakarta : LPPI, LPM, FAI UMY, Pustaka Suara Muhammadiyah.

Mulkhan, Abdul Munit. 2003. Dari Semar ke Sufi : Kesalehan Multikultural sebagai Solusi Islam di Tengah Tragedi Keagamaan Umat Manusia, Yogyakarta: al-Giyats.

Nakamura, Mitsua 1983. Agama dan Lingkungan Kultural Indonesia, Surakarta: Hapsara.

Peacock, James L. 1986. Gerakan Mubammadiyab Memurnikan Ajaran Islam di Indonesia, Jakarta: Cipta Kreatif.

Rais, M. Amin. 1995. Moralitas Politik Mubammadiyab, Yogyakarta: Dinamika.

Shihab, Alwi. 1997. Islam Inklusif, Bandung: Mizan.

1998. Membendung Arus, Respons Gerakan Mubammadiyab Terhadap Penetrasi Misi Kristen di Indonesia, Bandung: Mizan.

Smith, Margareth. 2001. Mistikus Islam, Surabaya: Risalah Gusti.

Sutatmin. 2000. Perikebidupan, Pengábdian dan Pemikiran AR. Fakhruddin dalam Mubammadiyab, Yogyakarta: Pustaka.

Taimiyah, Ibn. T.t. al-Furqon Bayn Auliya al-Rabman wa Auliya al-Syaitban, tp. 
190 Millab Vol. VIII, No. 1, Agustus 2008 1986. Tasaunf dan Kritik terhadap Filsafat, Terjemahan.

Tobroni. 2005. The Spiritual Leadersbip: Pengefektifan Organisasi, Noble Industry Melalui Prinsip-prinsip Spritual Etis, Malang: UMM Press. 